\title{
In Vitro Effect of Plant Parts Extract of Senecio glaucus L. on Pathogenic Bacteria
}

\author{
Mohammed Sabry Sultan 1(i) , Ashraf Elsayed ${ }^{1}$ (i) , Yasser Ahmed El-Amir 1,* (D) \\ 1 Botany Department, Faculty of Science, Mansoura University, Mansoura, 35516, Egypt \\ * Correspondence: yasran@ mans.edu.eg (Y.E.);
}

Scopus Author ID 55791223000

Received: 1.04.2021; Revised: 15.05.2021; Accepted: 19.05.2021; Published: 13.08.2021

\begin{abstract}
Senecio glaucus L. is an annual herb that grows in several Egyptian desert habitats. The diversity of habitats inhabited by this species, as well as its distribution, chemical composition, and biological activity, are all unknown. This research aimed to examine the chemical composition of S. glaucus from various environments in Egypt, as well as the antioxidant and antimicrobial activities. The general assessment of the analytical results for different parts of S. glaucus showed that the capitula and leaves in both inland and coastal samples were rich in bioactive constituents than the other parts as following (capitula $>$ leaf $>$ root $>$ stem). Based on the results of $\mathrm{IC}_{50}$, the antioxidant properties of the eight parts of two samples follows the sequence capitula $>$ root $>$ leaf $>$ stem for the coastal sample, and capitula $>$ leaf $>$ stem $>$ root for the inland sample. The IC50 values ranged from 25.94 to 41.20 $\mathrm{mg} / \mathrm{ml}$ in coastal sample, where the $\mathrm{IC}_{50}$ values ranged from 28.02 to $42.83 \mathrm{mg} / \mathrm{ml}$ in desert sample, compared to ascorbic acid $\left(\mathrm{IC}_{50}=13.30 \mathrm{mg} / \mathrm{ml}\right)$. The antimicrobial potential of $\mathrm{MeOH}$ extracts of $S$. glaucus parts collected from different habitats exhibited different inhibitory spectrum behavior with varying degrees of inhibition against six Gram-positive bacteria and four Gram-negative bacteria. In both coastal and inland samples, the $E$. coli inhibition zone was the most susceptible bacterium. Whereas, in the case of the coastal sample, the inhibition zone of B. subtilis was the most sensitive bacterium. The results of the antibacterial test were compared with 3 standard antibiotics.
\end{abstract}

Keywords: Senecio; Asteraceae; phytochemical; antioxidant; antimicrobial.

(C) 2021 by the authors. This article is an open-access article distributed under the terms and conditions of the Creative Commons Attribution (CC BY) license (https://creativecommons.org/licenses/by/4.0/).

\section{Introduction}

Millions of people worldwide depend on natural habitats and the wild plants that thrive there, which often act as a buffer against drought, scarcity, and hunger and play critical roles in maintaining livelihoods and well-being. This is especially true for those who live in the rural areas of many developing countries [1,2]. Hippocrates, who taught the art of healing by using plant-based medicines, used plants and their extracts to treat diseases around 460-370 BC. [3]. Medicinal plants are highly beneficial to people's and communities' well-being [4].

Although most research focuses on sustainable development and the need for advanced clean technology, returning to nature's potential for discovering and creating new pharmacological agents from renewable resources may be viable [5]. The main reason for this is that these natural derivatives have specific properties, including continuous immunomodulatory activity with high selectivity and efficacy. Generally, medicines contain just one active substance, synthetically, whereas medicinal plants, on the other hand, are simply a synergistic combination of dozens, if not hundreds, of natural chemicals [6,7]. Natural chemicals (secondary metabolites) are essential because they are used in various sectors, 
including pharmaceuticals, cosmetics, agricultural and industrial products, and dietary supplements [8-10]. Additionally, medicinal plants contain a high concentration of vitamins and minerals easily absorbed by the human body [6-11].

Asteraceae family (Compositae) is an extremely large and common Flowering plant family of 23,600 currently known species, divided into 1,620 genera and 13 subfamilies, found in temperate and tropical climates, with a strong presence in the Mediterranean and Western Asia. Several herbs were once used to treat microbial infections in traditional medicine [12]. In the flora of Egypt, Asteraceae is represented by about 228 species in 98 genera [13]. Many family members have commercial importance for human usage as; food, ornamentals, oil production, insecticides, medicinal practices, and industrial applications [14].

In Egypt, Senecio flavus, S. glaucus, S. vulgaris, S. aegyptius, S. belbeysius, and $S$. hoggariensis are found among the nearly 1250 Senecio species found worldwide [15]. This genus's botanical, pharmacological, and toxicological properties are significant [16-18]. In Egypt, Senecio species found in desert wadies and sandy plains are used as a central nervous system sedative, emetic, and diuretic [19]. Senecio glaucus L. (vernacular name, Morrar) is an annual herb with two subspecies (subsp.) that grow in Egypt. The first subsp. is S. glaucus subsp. glaucus and the second is S. glaucus subsp. coronopifloius (Maire) C. Alexander. Subsp. coronopifloius grow in dry, acidic soils along the coast, desert wadis, and the edges of agriculture and it is much more widespread throughout Egypt than subsp. glaucus [15].

A literature review on the phytochemical investigation of the aerial parts of Senecio species indicates a large variety of sesquiterpenoids [20], diterpenoids [21], triterpenoids [22], volatile oils [23], and alkaloids [20,24]. The different extracts isolated from Senecio showed antioxidant, antimicrobial, insecticidal antiviral properties, anti-inflammatory in vitro [25-28]. Therefore, this work aimed to examine the chemical composition of Senecio glaucus subsp. coronopifloius from different Egyptian habitats and investigate their antioxidant and antimicrobial properties for better exploitation of these natural products.

\section{Materials and Methods}

\subsection{Plant material collection and extract preparation.}

The entire plant of Senecio glaucus subsp. coronopifolius in the flowering stage was collected in March 2020 from Wadi Araba (Eastern Desert) and Gamesa City at Mediterranean coastal. Dr. Yasser A. El-Ameir, Lecturer of Plant Ecology, Botany Department, Faculty of Science, Mansoura University, Egypt, characterized the plant, according to Bolous [15]. A voucher specimen was deposited in the faculty of Sciences, Mansoura University.

The plant sample was handily cleaned, washed several times with distilled water, divided into four portions root, stem, leaf, and flower, dried for 24 hours at $55-60{ }^{\circ} \mathrm{C}$ in an airforced oven to reduce moisture content before grinding. 200 grams of each dried plant part was socked separately in $85 \%$ methanol and shake periodically. The dried residue was dissolved in dimethyl sulfoxide (DMSO) for further use after the extracts were filtered and evaporated.

\subsection{Antibacterial Bioassay.}

\subsubsection{Tested bacteria.}

The different extracts of Senecio glaucus were tested against four gram-negative bacteria, including Klebsiella pneumoniae (ATCC10031), Escherichia coli (ATCC10536), 
Salmonella typhi (ATCC25566), and Pseudomonas aeruginosa (ATCC9027) as well as six gram-positive bacteria, including Streptococcus epidermidis (EMCC1353t), Staphylococcus aureus (ATCC6538), Bacillus subtilis (DMS1088), Listeria monocytogenes (ATCC19116), Bacillus cereus (DMS30054), and Streptococcus pneumoniae (LAB3672).

2.2.2. Antibacterial activity.

Filter paper discs with a diameter of five milliliters were sterilized and immersed in the prepared plant extracts overnight before being loaded onto the nutrient agar medium seeded with the pathogenic microorganisms under investigation for the antibacterial assay [29]. After the agar plates had been incubated for 24 hours at $37^{\circ} \mathrm{C}$, the inhibition zone diameter $(\mathrm{mm})$ was measured.

2.3. Qualitative phytochemical screening.

The phytochemical components were identified using standard procedures as defined by Sofowora [30], Trease and Evans [31], and Harborne [32].

\subsection{Quantitative determination of the chemical constituents.}

Total phenolics, flavonoids, and alkaloids were determined using assays developed by Chlopicka et al. [33], Stankovic [34], and Jasuja et al. [35]. Obadoni and Ochuko [36] identified a method for evaluating saponins content, while tannins were defined by Van Buren and Robinson [37].

\subsection{Antioxidant activity.}

The free radical DPPH (1,1-diphenyl-2-picrylhydrazyl) was used to calculate antioxidant activity [38]. One milliliter of $0.15 \times 10^{-3} \mathrm{M}$ DPPH was applied to one milliliter of various concentrations of prepared extracts $(50,40,30,20,10$, and $5 \mathrm{ppm})$. One milliliter of DPPH was mixed with one milliliter of the solvent to make a control. The absorbance was estimated at $517 \mathrm{~nm}$ after thirty minutes of incubation at room temperature in the absence of light. IC 50 values were graphically determined, and the antioxidant activity was expressed as:

$$
\% \text { Radical scavenging activity }=\left[1-\frac{A_{\text {sample }}}{A_{\text {control }}}\right] * 100
$$

\subsection{Statistical analysis.}

The experiments were done in triplicates, and mean \pm standard deviation $(\mathrm{M} \pm \mathrm{SD})$ was measured. CoStat (CoHort Software, www.cohort.com, USA, version 6.311) was used to analyze the antimicrobial and antioxidant results, which was done using one-way ANOVA and Duncan's test at a probability level of 0.05 .

\section{Results and Discussion}

\subsection{Inhibitory effect of medicinal plant.}

The development of multidrug-resistant pathogenic bacteria in humans and animals, as well as the negative side effects of certain antibiotics, has sparked interest in developing and finding new plant-based antibiotics [39]. In this experiment, the antimicrobial potential of 
methanolic extracts of Senecio glaucus parts (root, stem, leaf, and capitula) collected from different habitats (coastal and inland desert) exhibited a wide variety of inhibitory spectrum behaviors against six Gram-positive bacteria and four Gram-negative bacteria, as measured by the diameters of inhibition zones formed by the extracts (Tables $1 \& 2$ ).

In the case of Gram-negative bacteria, the inhibition zone of Escherichia coli was found to be the most susceptible bacterium in the current study's coastal and inland desert samples. The most potent inhibitor of MeOH extract was Escherichia coli (root: 20 and 25mm, stem: 15 and $10 \mathrm{~mm}$, leaf: $15 \mathrm{~mm}$ each, capitula: 21 and $10 \mathrm{~mm}$ ) for coastal and desert samples, respectively. In comparison, Pseudomonas aeruginosa had negative results in the case of $\mathrm{MeOH}$ extracts of root and leaf for coastal sample, Although the findings for Klebsiella pneumoniae were negative in the case of $\mathrm{MeOH}$ extracts of stem for desert sample (Table 1). The results were compared to three standard antibiotics; Escherichia coli was shown to be the most active inhibitor of ampicillin, cefotaxime, and tetracycline antibiotics (20,30, and 20mm, respectively), followed by Klebsiella pneumoniae (5, 20, and 20mm, respectively). Pseudomonas aeruginosa was found to be ampicillin and tetracycline antibiotic-resistant, while Salmonella typhi was found to be ampicillin-resistant (Table 1).

Table 1. The antibacterial activities are represented by the inhibition zone diameter(mm*) of the extracted $\mathrm{MeOH}$ from Senecio glaucus and standard antibiotics.

\begin{tabular}{|c|c|c|c|c|c|}
\hline \multirow[b]{2}{*}{$\begin{array}{l}\text { Plant } \\
\text { sample }\end{array}$} & \multirow[b]{2}{*}{ Plant parts } & \multicolumn{4}{|c|}{ Gram-negative bacteria } \\
\hline & & Escherichia coli & $\begin{array}{c}\text { Klebsiella } \\
\text { pneumoniae }\end{array}$ & $\begin{array}{c}\text { Pseudomonas } \\
\text { aeruginosa }\end{array}$ & $\begin{array}{c}\text { Salmonella } \\
\text { typhi }\end{array}$ \\
\hline \multirow{4}{*}{$\begin{array}{l}\text { Coastal } \\
\text { sample }\end{array}$} & Root & 20 & 10 & NA & 19 \\
\hline & Stem & 15 & 10 & 6 & 15 \\
\hline & Leaf & 15 & 8 & $\mathrm{NA}$ & 1 \\
\hline & Capitula & 21 & 10 & 6 & 11 \\
\hline \multirow{4}{*}{$\begin{array}{l}\text { Desert } \\
\text { sample }\end{array}$} & Root & 25 & 12 & 8 & 7 \\
\hline & Stem & 10 & NA & 7 & 1 \\
\hline & Leaf & 15 & 13 & 6 & 5 \\
\hline & Capitula & 10 & 10 & 7 & 7 \\
\hline \multicolumn{6}{|c|}{ Standard antibiotic $\left(10 \mathrm{mg} \mathrm{L}^{-1}\right)$} \\
\hline \multicolumn{2}{|c|}{ Ampicillin } & 20 & 5 & NA & NA \\
\hline \multicolumn{2}{|c|}{ Cefotaxime } & 30 & 20 & 10 & 10 \\
\hline \multicolumn{2}{|c|}{ Tetracycline } & 20 & 20 & NA & 10 \\
\hline
\end{tabular}

*Values are average $(n=3)$, NA: Not active.

Table 2. The antimicrobial activities are represented by the inhibition zone diameter $(\mathrm{mm} *)$ of the extracted $\mathrm{MeOH}$ from Senecio glaucus and standard antibiotics.

\begin{tabular}{|c|c|c|c|c|c|c|c|}
\hline \multirow{2}{*}{$\begin{array}{l}\text { Plant } \\
\text { sample }\end{array}$} & \multirow{2}{*}{$\begin{array}{l}\text { Plant } \\
\text { parts }\end{array}$} & \multicolumn{6}{|c|}{ Gram-positive bacteria } \\
\hline & & $\begin{array}{c}\text { Bacillus } \\
\text { cereus }\end{array}$ & $\begin{array}{l}\text { Bacillus } \\
\text { subtilis }\end{array}$ & $\begin{array}{c}\text { Listeria } \\
\text { monocytogenes }\end{array}$ & $\begin{array}{c}\text { Staphylococcus } \\
\text { aureus }\end{array}$ & $\begin{array}{c}\text { Staphylococcus } \\
\text { epidermidis }\end{array}$ & $\begin{array}{l}\text { Streptococcus } \\
\text { pneumoniae }\end{array}$ \\
\hline \multirow{4}{*}{$\begin{array}{l}\text { Coastal } \\
\text { sample }\end{array}$} & Root & NA & 21 & NA & NA & 7 & 8 \\
\hline & Stem & NA & 10 & 7 & NA & 6 & 6 \\
\hline & Leaf & NA & 8 & NA & NA & 11 & 10 \\
\hline & Capitula & NA & 8 & 6 & NA & 7 & 6 \\
\hline \multirow{4}{*}{$\begin{array}{l}\text { Desert } \\
\text { sample }\end{array}$} & Root & NA & 15 & NA & NA & 7 & 6 \\
\hline & Stem & NA & 12 & NA & NA & 7 & 6 \\
\hline & Leaf & NA & 19 & NA & NA & 7 & 7 \\
\hline & Capitula & NA & 8 & NA & NA & 7 & 7 \\
\hline \multicolumn{8}{|c|}{ Standard antibiotic $\left(10 \mathrm{mg} \mathrm{L}^{-1}\right)$} \\
\hline \multicolumn{2}{|c|}{ Chloramphenicol } & 5 & 20 & 25 & 30 & 10 & 10 \\
\hline \multicolumn{2}{|c|}{ Gentamicin } & 10 & 5 & 20 & 22 & 20 & 11 \\
\hline \multicolumn{2}{|c|}{ Penicillin } & 10 & 23 & 20 & 20 & 20 & 15 \\
\hline
\end{tabular}

*Values are average $(n=3)$, NA: Not active

In this study, the $\mathrm{MeOH}$ extracts from two samples (coastal and desert) showed promising inhibitory activity against Gram-positive bacteria B. subtilis. The most potent 
inhibitor of $\mathrm{MeOH}$ extract was B. subtilis (root: 21 and 15mm, stem: 10 and 12mm, leaf: 19mm, capitula: $8 \mathrm{~mm}$ each) for coastal and desert samples, respectively. Whereas $S$. epidermidis is the most active inhibitor of leaf $\mathrm{MeOH}$ extract $(11 \mathrm{~mm})$ for the coastal sample. Moreover, in all $\mathrm{MeOH}$ extract from two samples of $S$. glaucus, the pathogens $S$. pneumoniae and $S$. epidermidis were the most susceptible bacteria. In contrast, B. cereus, L. monocytogenes, and S. aureus tested negative in root and leaf extracts for the coastal sample and all extracts from all sections of the desert sample. Furthermore, B. cereus and $S$. aureus were found to be immune to $\mathrm{MeOH}$ extracts from the stem and capitula for coastal samples (Table 2). The results were compared with three standard antibiotics; $S$. aureus was the most active inhibitor (30 and $22 \mathrm{~mm}$ ) of chloramphenicol and gentamicin, respectively, and B. subtilis was the most active inhibitor of penicillin (23 $\mathrm{mm}$ ), followed by L. monocytogenes (Table 2 ).

The overall susceptibility of E. coli (G-ve) and B. subtilis (G+ve) pathogens confirmed the findings of a previous preliminary investigation against $E$. coli and B. subtilis, respectively [40-42]. Also, Elsayed et al. [43] reported that Calotropis procera extract was found to have a major inhibitory effect against two Gram-positive (Bacillus subtilis and S. aureus) and two Gram-negative (E. coli and P. aeruginosa) bacteria. Based on the findings, gram-negative bacteria seem to be more susceptible to Senecio glaucus extracts than Gram-positive bacteria. Our previous studies on compounds isolated from wild species are in agreement with these findings $[10,28,44]$. The difference in sensitivity between Gram-negative and Gram-positive bacteria may be due to differences in cell wall structure $[45,46]$.

Since most plants have an amazing ability to produce a large range of secondary metabolites, such as alkaloids, glycosides, terpenoids, saponins, steroids, flavonoids, tannins, quinones, and coumarins, many wild plants exhibited inhibition zones of various diameters toward pathogens [47]. Plant-derived antimicrobial compounds are derived from these biomolecules [48]. In the treatment of bacterial infections, some natural products are beneficial. S. glaucus reportedly exhibits significant cytotoxic and antioxidant activities [49,50]. $S$. glaucus also produces bioactive compounds such as phenolics, saponins, flavonoids, and tannins, as well as certain volatile essential oils $[28,51,52]$.

\subsection{Phytochemical constituents.}

Phytochemical screening and qualitative of the powder and crude extract of S. glaucus parts (root, stem, leaves, and capitula) were performed. The results were recorded in Table 1. In this study, the use of different plant parts revealed different responses to the presence of phytoconstituents, and the terms of scores are used as,,,-+++++ , according to the intensity of color or precipitates generated. As a result, the qualitative estimation of the bioactive compounds in the parts of S. glaucus was observed. Within the same sample and between the coastal and the inland (desert) samples, S. glaucus displayed substantial variance. The two samples were rich in varying amounts of alkaloids, flavonoids, phenols, saponins, and tannins (Table 1). However, two samples have reported traces or absence of phytoconstituents. Glycosides and steroids were found in trace amounts (+) in both samples. Anthraquinones are absent (-) from the all-plant parts, either coastal or inland samples, whereas terpenoids are present in the stem and capitula parts and are absent from the root and leaf parts in both plants samples (Table 1). Several factors that influence the extraction of bioactive compounds from natural flora, including extraction method, raw materials, extraction solvent, plant species and age, and soil type, have to affect the phytochemical composition [53,54]. 
Table 3. Qualitative phytochemical analysis of four parts of Senecio glaucus collected from the Egyptian desert.

\begin{tabular}{l|c|c|c|c|c|c|c|c}
\multirow{2}{*}{ Screening test } & \multicolumn{9}{c}{ Costal glaucus } \\
\cline { 2 - 10 } & Root & Stem & Leaf & Capitula & Root & Stem & Leaf & Capitula \\
\cline { 2 - 10 } \\
\cline { 2 - 10 } Alkaloids & + & + & + & ++ & + & + & + & ++ \\
\hline Flavonoids & + & + & ++ & ++ & + & + & ++ & +++ \\
\hline Phenols & ++ & ++ & ++ & +++ & ++ & + & ++ & ++ \\
\hline Saponins & +++ & ++ & + & +++ & ++ & + & ++ & ++ \\
\hline Tannins & ++ & + & + & ++ & ++ & + & + & + \\
\hline Steroids & + & + & + & + & + & + & + & + \\
\hline Glycosides & + & + & + & + & + & + & + & + \\
\hline Anthraquinones & - & - & - & - & - & - & - & - \\
\hline Terpenes & - & + & - & + & - & + & - & +
\end{tabular}

A positive mark (+) indicates the presence of the phytochemical. A negative mark $(-)$ indicates the absence of the phytochemical.

The general assessment of the analytical results for different parts of S. glaucus showed individual specificity of each studied part and the rich, diverse spectrum of secondary metabolites differing from one another in both coastal and inland (desert) plant samples; and revealed that the capitula and leaves parts of both the inland and coastal samples were a rich source of saponins, tannins, phenols, flavonoids, and alkaloids than the other parts as following (capitula > leaf > root > stem); On the other hand, the inland plant sample produces comparable findings to the coastal sample, but with lower values (Figure 1). The highest total content of saponins, tannins, phenols, flavonoids, and alkaloids was found in plant costal sample was found in capitula $(22.10,14.75,13.37,7.08$, and $6.60 \mathrm{mg} / \mathrm{g})$ followed by leaf $(19.75,12.40$, $11.02,6.73$ and $4.25 \mathrm{mg} / \mathrm{g})$; Similar results were reported for inland sample capitula $(20.15$, $12.80,10.42,5.13$ and $3.62 \mathrm{mg} / \mathrm{g}$ ) followed by leaf $(17.80,10.45,9.07,4.78$ and $2.30 \mathrm{mg} / \mathrm{g}$ ) as shown in Figur 1. In this study, the phytochemical analysis of S. glaucus was significantly higher than that of El-Amier et al. [28] on the same species from the coastal desert. Furthermore, the total phenolic contents of Senecio plants grown in Egypt and Turkey were comparable [49,55]. These differences in bioactive constituents may be attributed to environmental variance, whereas the phytochemical composition has been shown to be influenced by geographical variability, temperature, and soil type [53,54,56].

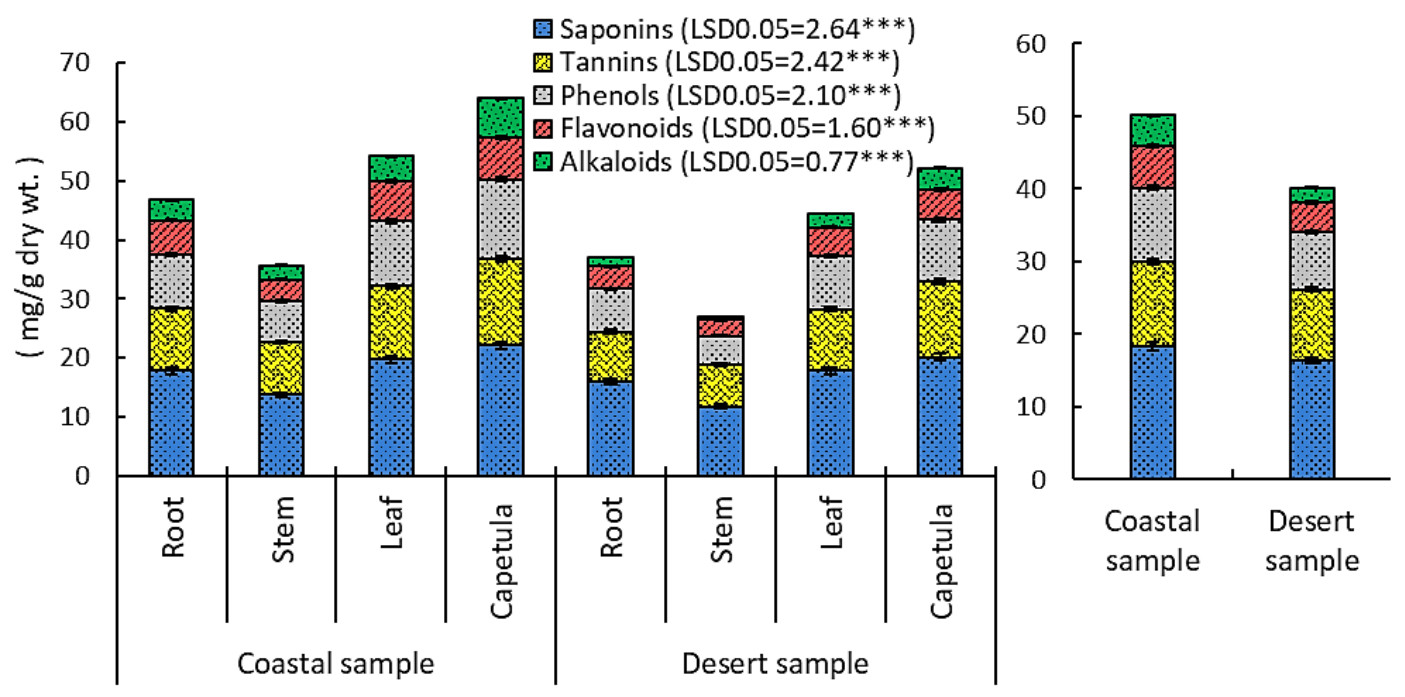

Figure 1. Secondary compounds ( $\mathrm{mg} \mathrm{g}^{-1} \mathrm{dry} \mathrm{wt}$ ) of Senecio glaucus collected from the Egyptian desert. 


\subsection{Antioxidant activity.}

The antioxidant activity of methanolic extracts from Senecio glaucus (root, stem, leaf, and capitula) was calculated using 2,2-diphenyl-1-picrylhydrazyl (DPPH) free radicals, with the concentration of an antioxidant required to reduce the initial levels of DPPH by $50 \%$ (IC50). The $\mathrm{IC}_{50}$ inverted the antioxidant force, whereas the lower the $\mathrm{IC}_{50}$, the higher the antioxidant activity [57]. In this experiment, ascorbic acid was used as a standard compound.

a)

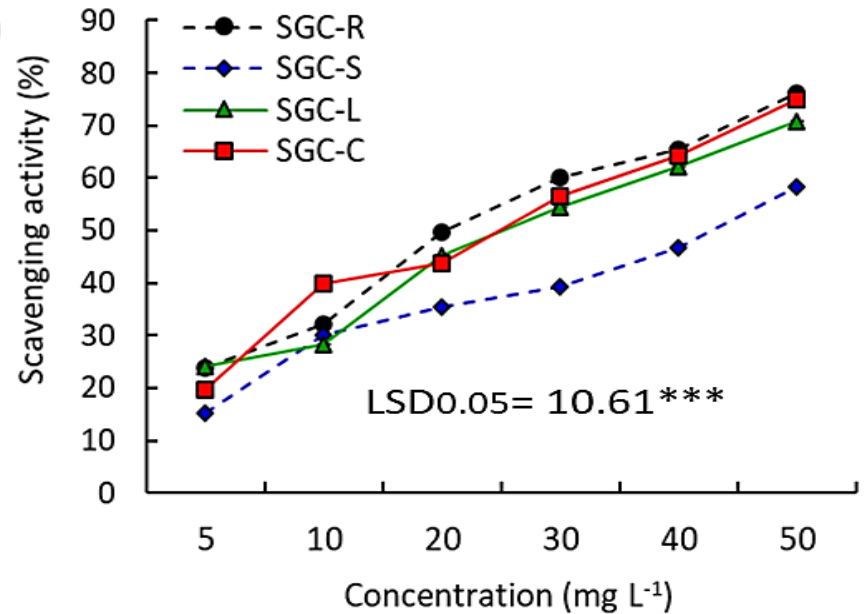

b)

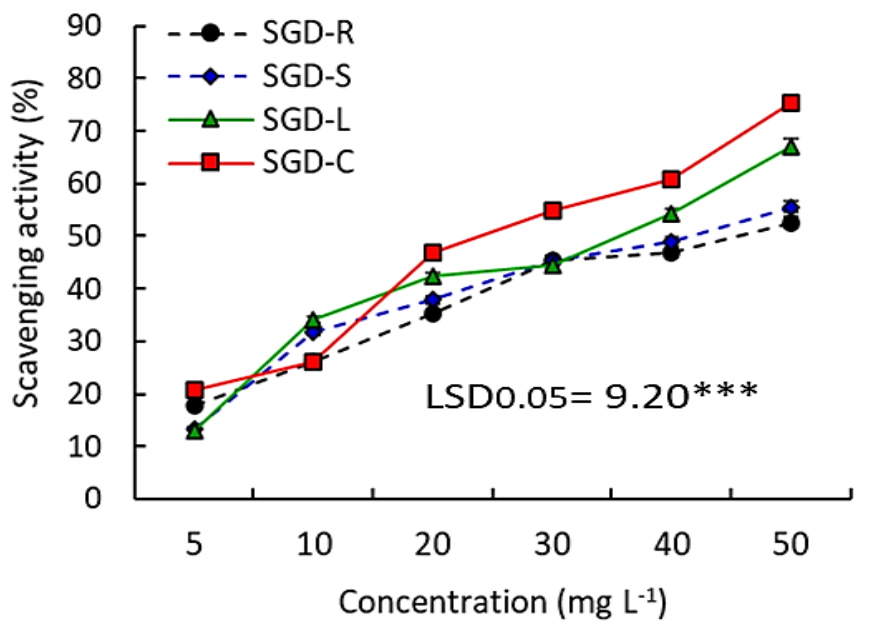

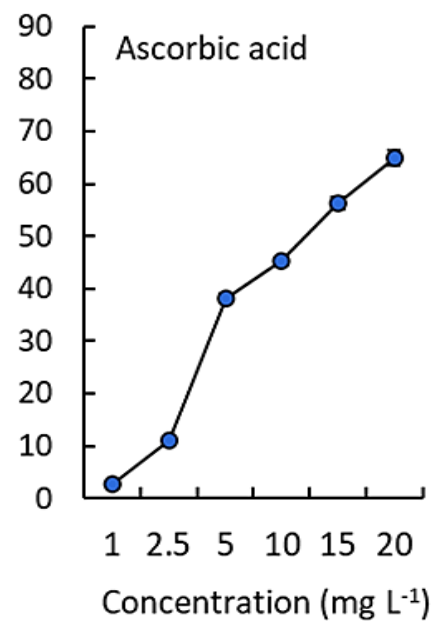

Concentration ( $\left.\mathrm{mg} \mathrm{L}^{-1}\right)$

Figure 2. Scavenging activity percentage of 2,2-Diphenyl-1-picrylhydrazyl (DPPH) by MeOH extract of Senecio glaucus collected from a) the coastal area and b) the inland desert as well as ascorbic acid as standard. (SGC-R: S. glaucus costal root, SGC-S: - stem, SGC-L: -leaf, SGC-C: -capitula, SGD-R: S. glaucus desert root, SGD-S: -stem, SGD-L: -leaf, SGD-C: -capitula).

According to the findings, methanolic extracts of Senecio glaucus had an antioxidant activity that was dose-based $(\mathrm{P} \leq 0.05)$ and comparable to ascorbic acid as a reference norm (Figure 2). At $50 \mathrm{mg} / \mathrm{ml}$, the extracts of root, stem, leaf and capitula showed scavenging activities of $76.17 \%, 58.23 \%, 70.68 \%$ and $74.97 \%$ for coastal sample, and $52.61 \%, 55.56 \%$, $67.20 \%$ and $75.23 \%$ for inland sample, respectively. However, the lowest concentration (5 $\mathrm{mg} / \mathrm{ml}$ ) shows the lowest antioxidant activity in the two samples (Figure 2).

Based on the results of $\mathrm{IC}_{50}$, the antioxidant activity of the eight parts of two samples follows the sequence capitula $>$ root $>$ leaf $>$ stem for coastal sample, and capitula $>$ leaf $>$ stem $>$ root for inland sample (Figure 3). In the present study, the IC50 values ranged from 25.94 to $41.20 \mathrm{mg} / \mathrm{ml}$ in the coastal sample, where the capitula extract showed the highest antioxidant activity by $\mathrm{IC}_{50}=25.94 \mathrm{mg} / \mathrm{ml}$, while the stem extract showed the lowest antioxidant activity by $\mathrm{IC}_{50}=41.20 \mathrm{mg} / \mathrm{ml}$. On the other side, the $\mathrm{IC}_{50}$ values ranged from 28.02 
to $42.83 \mathrm{mg} / \mathrm{ml}$ in the desert sample, where the capitula extract showed the highest antioxidant activity by $\mathrm{IC}_{50}=28.02 \mathrm{mg} / \mathrm{ml}$, while the root extract showed the lowest antioxidant activity by $\mathrm{IC}_{50}=42.83 \mathrm{mg} / \mathrm{ml}$ (Figure 3 ). All the tested extracts have shown antioxidant scavenging activities but with values higher than that of ascorbic acid ( $\mathrm{IC}_{50}=13.30 \mathrm{mg} / \mathrm{ml}$ ).

$S$. glaucus $\mathrm{MeOH}$ extract could be attributed to the antioxidant activity of major compounds, such as volatiles [51,52], phenolics, saponins, flavonoids, and tannins [28,52], antimicrobial [28], cytotoxic [49], antioxidant and anticancer properties [50]. Besides, the $\mathrm{MeOH}$ extract from $S$. glaucus, which grew in Egypt, has been found to have antioxidant activity using the DPPH method, $\mathrm{IC}_{50}=79.57 \pm 0.74 \mu \mathrm{g} / \mathrm{mL}$. Species of the genus of Senecio are known to be rich in alkaloid and phenolic composites [24,49,55]. Recent studies have demonstrated the significant contribution of many flavonoids, phenolic, and alkaloids to the full antioxidant activity of many medicinal plants $[10,58]$.

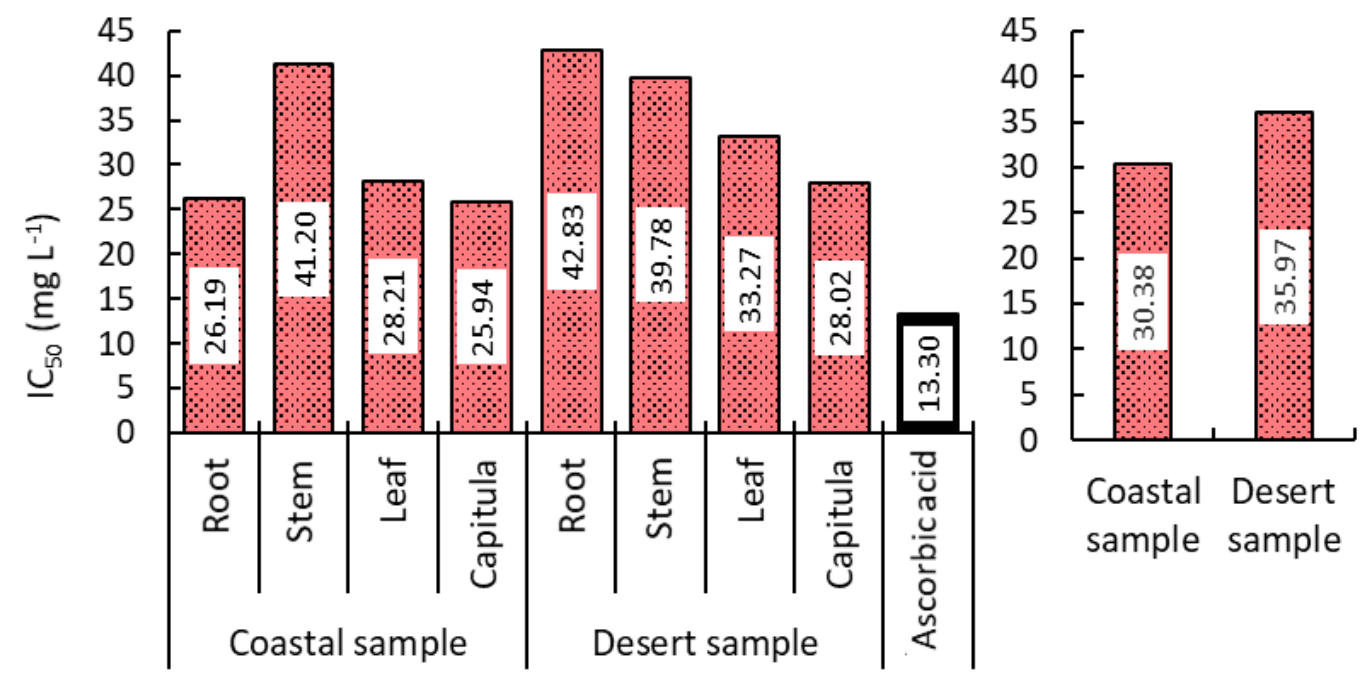

Figure 3. $\mathrm{IC}_{50}$ values of the different parts of Senecio glaucus collected from the Egyptian desert and ascorbic acid (standard).

\section{Conclusions}

Finally, Senecio glaucus is major wildlife used in traditional medicine for the treatment of many diseases. This study demonstrated that $S$. glaucus can become a sustainable source of antimicrobials because of the good inhibitory action against Klebsiella pneumoniae, Escherichia coli, Pseudomonas aeruginosa, Salmonella typhi, Staphylococcus epidermidis, Bacillus subtilis, and Streptococcus pneumoniae. S. glaucus could also serve as an advantageous source for antioxidants and green materials with antioxidant scaping (30.38$35.97 \mathrm{mg} / \mathrm{ml}$ ) but higher than ascorbic acid levels ( $\mathrm{IC}_{50}=13.30 \mathrm{mg} / \mathrm{ml}$ ). Besides, the phytochemicals of S. glaucus can be used as a raw material to produce cheaper pharmaceuticals and many more important commercialized products of public use.

\section{Funding}

This research received no external funding.

\section{Acknowledgments}

This research has no acknowledgment. 


\section{Conflicts of Interest}

The authors declare no conflict of interest.

\section{References}

1. Cao, Y.; Natuhara, Y. Effect of urbanization on vegetation in riparian area: Plant communities in artificial and semi-natural habitats. Sustainability 2020, 12, 204, https://doi.org/10.3390/su12010204.

2. Sharrock, S.; Jackson P.W. Plant conservation and the sustainable development goals: A policy paper prepared for the global partnership for plant conservation. Annals of the Missouri Botanical Garden 2017, 102, 290-302, https://doi.org/10.3417/D-16-00004A.

3. Sofowora, E. Traditional Medicine Methods and Techniques, 1982, John Wiley and Son Ltd., New York.

4. Zahran, M.A.; El-Amier, Y.A. Non-traditional fodders from the halophytic vegetation of the deltaic Mediterranean coastal desert, Egypt. Journal of Biological Science 2013, 13, 226-233, https://doi.org/10.3923/jbs.2013.226.233.

5. Mondal, P.; Dalai, A.K. Sustainable utilization of natural resources. 2017, CRC Press.

6. Lautié, E.; Russo, O.; Ducrot, P.; Boutin, J.A. Unraveling plant natural chemical diversity for drug discovery purposes. Frontiers in Pharmacology 2020, 11, 397, https://doi.org/10.3389/fphar.2020.00397.

7. Segneanu, A.E.; Velciov, S.M.; Olariu, S.; Cziple, F.; Damian, D.; Grozescu, I. Bioactive molecules profile from natural compounds. Amino Acid-New Insights and Roles in Plant and Animal; Asao, T., Ed. 2017, 209228, https://dx.doi.org/10.5772/intechopen.68643.

8. Saroya, A.S.; Singh, J. Pharmacotherapeutic potential of natural products in neurological disorders. 2018, Springer.

9. El-Amier, Y.A.; Abo-Aisha, I.A. Phytochemical constituents of common growing Fagonia species (Zygophyllaceae) in Egyptian deserts and its biological activities. Plant Archives 2019, 19, 2213-2219.

10. El-Amier, Y.A.; Al-hadithy, O.N.; Fahmy, A.A.; El-Zayat, M.M. Phytochemical analysis and biological activities of three wild Mesembryanthemum species growing in heterogeneous habitats. Journal of Phytology 2021, 13, https://doi.org/10.25081/jp.2021.v13.6403.

11. Nguyen, L.A.; He, H.; Pham-Huy, C. Chiral drugs: an overview. International Journal of Biomedical Science 2006, 2, 85, https://www.ncbi.nlm.nih.gov/pmc/articles/PMC3614593.

12. Tamokou, J.; Mbaveng, A.; Kuete, V. Antimicrobial activities of African medicinal spices and vegetables. Medicinal spices and vegetables from Africa, Elsevier, 2017, 207-237, https://doi.org/10.1016/B978-0-12809286-6.00008-X.

13. Boulos, L. Flora of Egypt Checklist, revised annotated edition. Cairo, 2009, 198-201.

14. Fadhillah, L.; Rasnovi, S.; Thomy, Z. Utilization of Asteraceae family as medicinal plant by local community of hutan pinus Jantho nature reserve, Aceh Besar. Jurnal Natural 2021, 21, 5-9, https://doi.org/10.24815/jn.v21i1.17939.

15. Boulos, L. Flora of Egypt. Vol. 3 (Verbenaceae-Compositae). Nordic Journal of Botany 2002, 22, 390-390, https://doi.org/10.1111/j.1756-1051.2002.tb01389.x.

16. Bandyopadhyay, S.; Ganguly, S.; Mandal, G.; Sen, R.; Saha, P.; Ghosh, M.K.; Sarkar, M.; Chatterjee, M. Cytotoxicity of Senecio in macrophages is mediated via its induction of oxidative stress. Research in Veterinary Science 2009, 87, 85-90, https://doi.org/10.1016/j.rvsc.2008.12.007.

17. Singh, D.; Satish, C.; Manisha, D.S. Chemical and potential biological perspectives of genus Senecio (Asteraceae). European Journal of Pharmaceutical and Medical Research 2017, 4, 200-222, https://doi.org/10.4103/pr.pr_149_17.

18. Ebadi, M.; Rosa E. Morphological and genetic diversity of Senecio vulgaris L.(Asteraceae) in Iran. Acta Botanica Croatica 2021, 80, https://doi.org/10.37427/botcro-2021-012.

19. Eissa, T.A.F.; Palomino, O.M., Carretero, M.E.; Gómez-Serranillos, M.P. Ethnopharmacological study of medicinal plants used in the treatment of CNS disorders in Sinai Peninsula, Egypt. Journal of Ethnopharmacology 2014, 151, 317-332, https://doi.org/10.1016/j.jep.2013.10.041.

20. Bohlmann, F.; Ziesche, J. Sesquiterpenes from three Senecio species. Phytochemistry 1981, 20, 469-472, https://doi.org/10.1016/S0031-9422(00)84168-0.

21. Rücker, G.; Manns, D.; Schenkel, E.P.; Hartmann, R.; Heinzmann, B.M. Triterpenes with a new 9-epicucurbitan skeleton from Senecio selloi. Phytochemistry 1999, 52, 1587-1591, https://doi.org/10.1016/S0031-9422(99)00276-9.

22. Cheng, D.L.; Cao, X.P.; Cheng, J.K.; Roeder, E. Diterpene glycosides from Senecio rufus. Phytochemistry 1992, 32, 151-153, https://doi.org/10.1016/0031-9422(92)80122-U.

23. Pérez, C.; Agnese, A.M.; Cabrera, J.L. The essential oil of Senecio graveolens (Compositae): chemical composition and antimicrobial activity tests. Journal of Ethnopharmacology 1999, 66, 91-96, https://doi.org/10.1016/S0378-8741(98)00204-9.

24. Hussain, S.H.; Latif, A.; Arfan, M.; Mumtaz, A.; Simpson, T.J.; Cox, R.J.; Shaheen, F.; Uddin, G. A New Bezoxepine Derivative from Senecio desfontainei. Records of Natural Products 2013, 7, 325-331. 
25. Kahriman, N.; Tosun, G.; Terzioglu, S.; Karaoglu, S.A.; Yayli, N. Chemical composition and antimicrobial activity of the essential oils from the flower, leaf, and stem of Senecio pandurifolius. Records of Natural Products 2011, 5, 82.

26. Joshi, A.; Bhobe, M.; Sattarkar, A. Phytochemical investigation of the roots of Grewia microcoslinn. Journal of Chemical and Pharmaceutical Research 2013, 5, 80-87.

27. El-Amier, Y.A.; Abdelghany, A.M.; Abed Zaid, A. Green synthesis and antimicrobial activity of Senecio glaucus-mediated silver nanoparticles. Research Journal of Pharmaceutical, Biological and Chemical Sciences 2014, 5, 631-642.

28. Zaher, A.M.; Sultan, R.; Ramadan, T.; Amro, A. New antimicrobial and cytotoxic benzofuran glucoside from Senecio glaucus L. Natural Product Research 2020, 1, 1-6, https://doi.org/10.1080/14786419.2020.1768089.

29. Cappuccino J.G.; Sherman N. Microbiology: A laboratory Manual. Peason Benjamin Cummings. San Francisco, US, 2008.

30. Sofowora, A. Screening plants for bioactive agents. In Medicinal Plants and Traditional Medicinal in Africa. 2nd Ed. Spectrum Books Ltd, Sunshine House, Ibadan, Nigeria, 1993, 134-156.

31. Trease, G.E.; Evans, W.C. Pharmacognosy (13th edn). Bailliere Tindall, London, 1989, 176-180.

32. Harborne, J.B. Phenolic compounds, In Phytochemical methods, Springer, Dordrecht, 1973, 33-88, https://doi.org/10.1007/978-94-009-5921-7_2.

33. Chlopicka, J.; Pasko, P.; Gorinstein, S.; Jedryas, A.; Zagrodzki, P. Total phenolic and total flavonoid content, antioxidant activity and sensory evaluation of pseudocereal breads, LWT-Food Science and Technology 2012, 46, 548-555, https://doi.org/10.1016/j.lwt.2011.11.009.

34. Stankovic, M.S. Total phenolic content, flavonoid concentration and antioxidant activity of Marrubium peregrinum L. extracts. Kragujevac Journal of Science 2011, 33, 63-72.

35. Jasuja, N.D.; Sharma, S.K.; Saxena, R.; Choudhary, J.; Sharma, R.; Joshi, S.C. Antibacterial, antioxidant and phytochemical investigation of Thuja orientalis leaves. Journal of Medicinal Plants Research 2013, 7, 18861893, https://doi.org/10.5897/JMPR12.1323.

36. Obadoni, B.O.; Ochuko, P.O. Phytochemical studies and comparative efficacy of the crude extracts of some haemostatic plants in Edo and Delta States of Nigeria. Global Journal of Pure and Applied Sciences 2002, 8, 203-208, https://doi.org/10.4314/gjpas.v8i2.16033.

37. Van Buren, J.P.; Robinson, W.B. Formation of complexes between protein and tannic acid. Journal of Agricultural and Food Chemistry 1969, 17, 772-777, https://doi.org/10.1021/jf60164a003.

38. Miguel, M.G.; Cruz, C.; Faleiro, L.; Simões, M.T.; Figueiredo, A.C.; Barroso, J.G.; Pedro, L.G. Foeniculum vulgare essential oils: chemical composition, antioxidant and antimicrobial activities. Natural product communications 2010, 5, https://doi.org/10.1177\%2F1934578X1000500231.

39. AlSheikh, H.M.A.; Sultan, I.; Kumar, V.; Rather, I.A.; Al-Sheikh, H.; Tasleem Jan, A.; Haq, Q.M.R. Plantbased phytochemicals as possible alternative to antibiotics in combating bacterial drug resistance. Antibiotics 2020, 9, 480, https://doi.org/10.3390/antibiotics9080480.

40. Pauw, E.; Eloff, J.N. Which tree orders in southern Africa have the highest antimicrobial activity and selectivity against bacterial and fungal pathogens of animals? BMC Complementary and Alternative Medicine 2014, 14, 1-12, https://doi.org/10.1186/1472-6882-14-317.

41. Rahman, M.M.; Shahriar, M.R.; Meghla, N.S.; Ishika, T.; Roy P.C.; Kamruzzaman, M. Antimicrobial activity of some medicinal plant extracts against Gram positive and Gram-negative bacteria in Bangladesh. Asian Journal of Medical and Biological Research 2017, 3, 405-411, https://doi.org/10.3329/ajmbr.v3i4.35329.

42. Sapkota, P.; Bhattarai, S.; Bajracharya, A.M.; Lakhe, P.B.; Shrestha, N. Antimicrobial screening of some medicinal plants against selected bacterial species. Scientific World 2020, 13, 20-23, https://doi.org/10.3126/sw.v13i13.30500.

43. Elsayed, A.; Alyamani, A.; Ahmad, A.A.; El-Amier, Y.A. Antibacterial activity of Calotropis procera against some common human pathogens. International Journal of Research in Pharmaceutical Sciences 2020, 11, 3016-3022, https://doi.org/10.26452/ijrps.v10i4.

44. Arend, K.I.; Schmidt, J.J.; Bentler, T.; Lüchtefeld, C.; Eggerichs, D.; Hexamer, H.M.; Kaimer, C. Myxococcus xanthus predation of Gram-positive or Gram-negative bacteria is mediated by different bacteriolytic mechanisms. Applied and Environmental Microbiology 2021, 87, https://doi.org/10.1128/AEM.02382-20.

45. Elisha, I.L.; Botha, F.S.; McGaw, L.J.; Eloff, J.N. The antibacterial activity of extracts of nine plant species with good activity against Escherichia coli against five other bacteria and cytotoxicity of extracts. BMC Complementary and Alternative Medicine 2017, 17, 1-10, https://doi.org/10.1186/s12906-017-1645-z.

46. Hernández, S.B.; Cava, F., 2021. New approaches and techniques for bacterial cell wall analysis. Current Opinion in Microbiology 2021, 60, 88-95, https://doi.org/10.1016/j.mib.2021.01.010.

47. Das, K.; Tiwari, R.K.S.; Shrivastava, D.K. Techniques for evaluation of medicinal plant products as antimicrobial agent: Current methods and future trends. Journal of Medicinal Plants Research 2010, 4, 104111, https://doi.org/10.5897/JMPR09.030.

48. Srivastava, J.; Chandra, H.; Nautiyal, A.R.; Kalra, S.J. Antimicrobial resistance (AMR) and plant-derived antimicrobials (PDA ms) as an alternative drug line to control infections. Biotech 2014, 4, 451-460, https://doi.org/10.1007/s13205-013-0180-y. 
49. Mohamed, S. Phytochemical and biological study of Senecio glaucus subsp. coronopifolius (Maire) c. alexander growing in Egypt. Al-Azhar Journal of Pharmaceutical Sciences 2015, 52, 283-298, https://dx.doi.org/10.21608/ajps.2015.12566.

50. Alqahtani, A.S.; Herqash, R.N.; Noman, O.M.; Nasr, F.A.; Alyhya, N.; Anazi, S.H.; Farooq, M.; Ullah, R. In vitro antioxidant, cytotoxic activities, and phenolic profile of Senecio glaucus from Saudi Arabia. EvidenceBased Complementary and Alternative Medicine 2020, https://doi.org/10.1155/2020/8875430.

51. De Pooter, H.L.; De Buyck, L.F.; Schamp, N.M.; Aboutabl, E.; De Bruyn, A.; Husain, S.Z. The volatile fraction of Senecio glaucus subsp. coronopifolius. Flavour and Fragrance Journal 1986, 1, 159-163, https://doi.org/10.1002/ffj.2730010406.

52. El-Shazly, A.M. Essential oil composition of Senecio desfontainei Druce (Compositae). Zagazig Journal of Pharmaceutical Sciences 1999, 8, 1-8.

53. Tiwari, B.K. Ultrasound: A clean, green extraction technology. TrAC Trends in Analytical Chemistry 2015, 71, 100-109, https://doi.org/10.1016/j.trac.2015.04.013.

54. Câmara, J.S.; Albuquerque, B.R.; Aguiar, J.; Corrêa, R.C.; Gonçalves, J.L.; Granato, D.; Pereira, J.A.; Barros, L.; Ferreira, I.C. Food Bioactive Compounds and Emerging Techniques for Their Extraction: Polyphenols as a Case Study. Foods 2021, 10, 37, https://doi.org/10.3390/foods10010037.

55. Albayrak, S.; Aksoy, A.; Yurtseven, L.; Yaşar, A. A comparative study on phenolic components and biological activity of some Senecio species in Turkey. Journal of Pharmacy and Pharmacology 2014, 66, 1631-1640, https://doi.org/10.1111/jphp.12288.

56. Walia, S.; Mukhia, S.; Bhatt, V.; Kumar, R.; Kumar, R. Variability in chemical composition and antimicrobial activity of Tagetes minuta L. essential oil collected from different locations of Himalaya. Industrial Crops and Products 2020, 150, 112449, https://doi.org/10.1016/j.indcrop.2020.112449.

57. Moradi, H.; Ghavam, M.; Tavili, A. Study of antioxidant activity and some herbal compounds of Dracocephalum kotschyi Boiss in different ages of growth. Biotechnology Reports 2020, 25, e00408, https://doi.org/10.1016/j.btre.2019.e00408.

58. Zaki, A.A.; Ali, Z.; Wang, Y.H.; El-Amier, Y.A.; Khan, S.I.; Khan, I.A. Cytotoxic steroidal saponins from Panicum turgidum Forssk. Steroids 2017, 125, 14-19, https://doi.org/10.1016/j.steroids.2017.06.003. 